\title{
A Systematic Review of Philippine Research Productivity: A Bourdieusian Perspective
}

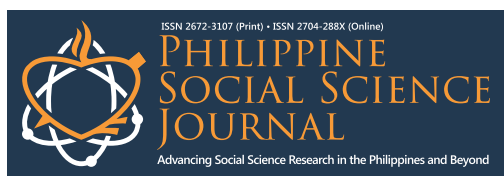

Holden Kenneth G. Alcazaren

Gen. Pantaleon Garcia Senior High School, Imus, Cavite, Philippines

\section{Article history:}

Submitted: 4 November 2021

Revised: 9 December 2021

Accepted: 21 December 2021

\section{Keywords:}

Research productivity

Systematic literature review

Capital theory

Faculty members

Bourdieusian perspective

ABSTRACT. In a neoliberal globalized institution, research productivity (RP) among faculty members has become an important aspect determining university rankings and academic performance. Coping with the demands of RP, many universities aim to improve their faculty's scholarly academic repertoire through incentivizing research publications and providing research training programs. Drawing from sociological perspectives, this systematic review outlines the factors and consequences of research productivity as a capital in the context of Philippine academics. Based on the review, one glaring issue is the low RP of the country compared to its ASEAN and Western counterparts across both soft and hard sciences. Using Bourdieu's theory on capital, the constant accumulation of faculty members for RP as capital has resulted in their struggle for legitimization in their professions and overcoming the paradox of national policies and institutional policies. Moreover, the review revealed additional pressure for faculty members to keep up with the demands of national policies requiring scholarly outputs while struggling to handle various institutional practices that can be restrictive towards research works.

\subsection{Introduction}

In determining sources that shape the core values of higher education $(\mathrm{HE})$ in the $21^{\text {st }}$ century, scholars have been critical towards the ruling neoliberal ideologies and imposition of a globalized university, mainly referred to as neoliberal globalization (Beckmann \& Cooper, 2013; Giroux, 2002; 2012; Levidow, 2002). With many contesting the notion and significant implications of globalization, Bourdieu (2002) argues that this concept is nothing but politics. For this reason, a politics of opposition to its concentration of power is possible. Within neoliberal globalization's assumptions, liberalizing welfare services like education is compelled in the interests of global capitalism as restoration of markets in society is perceived as a direct cause for positive human well-being (Beckmann \& Cooper, 2013). This assumption prioritizes market liberalism, which views markets as a fundamentally more efficient and reasonable entity than state-initiated bureaucratic policies.

As a result of this neoliberalism's market-driven discourse, higher education institutions (HEIs) construct their internalized notion of success and entitlement based on corporate cultures. Giroux (2002, p. 429) describes this corporate culture as "an ensemble of ideological and institutional forces that functions politically and pedagogically both to govern organizational life through senior managerial control and to fashion compliant workers, depoliticized consumers, and passive citizens. This 'corporatization' enacts inherent change in how HEIs appropriated culture, practices, and workforce strategies aligned to corporations (Steck, 2003). In these neoliberal hegemonic ideologies of HEIs, constructed performance targets and indicators are highly favored over academic creativity, reflective practice, and ethical issues (Beckmann \& Cooper, 2013). These performance constructions and measurements included quantifiable measures like graduate employment rates, faculty-student ratios, student evaluation scores, and, most notable, faculty research productivity.

Research productivity (RP) has become a major determinant that reflects the extent of academic institutions in generating knowledge (Alghanim \& Alhamali, 2011) and is considered as one of the major indicators for university rankings and university academic performance (Jung, 2012). The notion of RP is associated with two constructs: (a) Exploration, which implies a carefully detailed examination of phenomena to discover new realities; and (b) Efficiency, which implies its production delivered in the length of time (Batool et al., 2018). Even with no single definition, RP is typically defined by the number of publications in academic journals and scholarly books (Alhija \& Majdob, 2017).

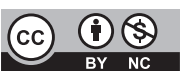

This article published by Philippine Social Science Journal (PSSJ) is licensed under a Creative Commons AttributionNoncommercial 4.0 International (CC BY-NC 4.0). You are free to share (copy and redistribute the material in any medium or format) and adapt (remix, transform, and build upon the material). Under the following terms, you must give appropriate credit, provide a link to the license, and indicate if changes were made. You may do so in any reasonable manner, but not in any way that suggests the licensor endorses you or your use. You may not use the material for commercial purposes. 
Keeping up with the demands of faster and greater numbers of research production and outputs has been one of the major goals of different universities (Altbach, 2011). Because of this, HEIs have been tasked and invested by governments and private sectors to create human intellectual capital and function in the educational, social, and cultural development of an economic society (De Villiers \& Steyn, 2009). As a result, RP has become a basis for attaining academic success, especially relating to tenureship, faculty promotion, and increased salary (Bloedel, 2001; Kotrlik et al., 2002; White et al., 2012). Research publications, particularly in Western countries, have become important factors for faculty members to have mobility in the academic hierarchies (Ju, 2010).

Currently, universities are considered "producers of new knowledge" (Iqbal \& Mahmood, 2011), where academicians and teachers' roles are no longer limited to teaching but also research publications. Indeed, the extent of these institutions' contributions to generating new knowledge reflects their research productivity. Accordingly, universities are looking into improving and expanding their faculty's scholarly academic repertoire (Bland et al., 2005). For these institutions, teaching and research are given equal importance as participation in research directly improves the quality of teaching (Cresswell, 1986; Middaugh, 2000) and contributes to the faculty's professional development (Livingston et al., 2009). Therefore, fostering the research capacity of faculty members is a way to enrich and improve the quality of student and teacher learning (Alhija \& Majdob, 2017).

In studying RP, previous literature has been largely quantitative in nature and segments influential factors into two extensive categories: individual-level features and institutional characteristics. To investigate RP, studies looked into variables that concern individual traits, like demographic characteristics and psychological conditions. For instance, the study of Alhija and Majdob (2017) found that among their sample population of Israeli teacher educators $(n=161)$, higher-ranking teachers are more research productive than their lower-ranking counterparts, which can be attributed to their networks of professional organizations and resources. In parallel, Lertputtarak (2008)'s qualitative case study $(n=11)$ revealed how the age of lecturers could be a significant determinant of research outcomes. Moreover, the findings of Batool et al. (2018) among public teachers in Pakistan $(n=290)$ showed how teaching experience have a statistical impact on faculty research engagement. In terms of the psychological conditions of faculty, Zhang (2014)'s dissertation showed that academic staff's motivation to do research comes from the need for faculty promotion or appraisal and the need to meet the requirement of the university performance evaluation. These findings are seconded by the study of Peng and Gao (2019) among Chinese academics $(n=309)$ that exhibited strong extrinsic motivation to do research in the form of external and identified university regulations.

Another determinant of faculty RP is institutional characteristics, including workload and research culture. In the study of Jung (2012), the workload is generally referred to as the amount of time devoted to any academic activity which appears to extensively influence RP. On the other hand, Kusure et al.'s (2006) interrogation of RP among lecturers $(n=50)$ in Zimbabwe revealed research culture as a necessary pre-condition for research production and dissemination. This finding is also similar to the results of other literature (Barker, 2005; Borg, 2007).

In studying RP in the Philippine context, it is noteworthy to discuss the characteristics and the capacity for research of the university setting where faculty members are situated. One important aspect in investigating RP in the country is the transition of the University of the Philippines (UP), the national university of the country, into a research university. Using Humboldt's philosophy of education, the two-part article of Demeterio and Pada (2018; 2019) on UP being the flagship of Philippine higher education provides an extensive historical account of the university's developments, pitfalls and progress in claiming its own rights as a research university. Historically, UP was established during the American colonial period having aspirations to become an American-style research university in the form of its faculty and graduate programs. During the great depression, however, UP has emphasized its ability for teaching and civil service to keep people employed that led to the dichotomization of teaching and research as separate tasks. The dichotomized activities of teaching and research have steered the university away from a Humboldtian educational system that "offers a stable, sustainable, progressive, and autonomous unity between stakeholders that advance the interests of the state, students, and professors in the pursuit of infinite knowledge" (Demeterio \& Pada, 2019, p. 69). The authors concluded that UP, being a functional research university, should no longer dichotomize teaching and research, and even contending, extension work where resources and time are allocated in concentrating on the pursuit of knowledge. 
In the Philippine context where there are no distinguished functional research universities, the study utilizes Pierre Bourdieu's perspectives on academic and intellectual traditions as reflected in his past works like Homo Academicus (Bourdieu, 1988). With RP inextricably linked to the professional development of faculty members, this analysis draws on Bourdieusian concepts of habitus, field, and capital. Drawing from these sociological perspectives, the increasing demand and institutional prestige of research production can be relatively associated with Wilensky (1964)'s critique of "sociological romance" of "professionalization of everyone," among the university faculty members at least. In this paper, RP can be seen as a form of capital in what Bourdieu (1994) and Noordegraaf \& Schinkel (2011) defined as a "field of power." In order to conceptualize RP as a capital, the paper outlines the factors that impact research engagement in HEIs as part of the social structure where individuals, i.e., university faculty members, accumulate forms of capitals.

In this review and analysis, I try to examine the key findings of selected studies that tackle Philippine research productivity in various contexts and disciplines. I also interrogated the predictors and factors that impact the RP of faculty members in different educational settings and institutions. Using Bourdieu (1977)'s capital theory, I try to understand research and research production as resources deemed worthy in a particular social formation; and individual 'practices' that maximize these resources or symbolic benefit to derive social advantages. I also argue that research productivity is determined and functions as faculty members' capital within institutional structures. I also examine how research practices and policies within these institutions contribute to creating capitals (e.g., economic, cultural, social, and symbolic) within these structured systems. With Bourdieu (1989)'s conceptualizations of capital, these relations within HEIs become objects of struggles among its faculty members as valued resources.

\subsection{Framework of the Study}

With the purpose to educate, HEIs are organizations made up of groups of people across various sections of society. Drawing from Pierre Bourdieu's theories on cultural and social practice, the paper examines how various meanings, values, and social understandings of these institutions influence research practices and policies within their faculty members. Bourdieu's (1984)'s theories examine social structures through people's behavior, communication, aspirations, and view of their existence as determined by their "social group" and its dynamics, referred to as 'practices'. Bourdieu explained that the convergence of habitus and capital as applied to a particular social context may modify these practices. Habitus, also termed as disposition, pertains to the "internalization of social structures as lived by actors" (Deem \& Lucas, 2007, p. 118). Habitus is a system of "schemas of perception and discrimination" individuals use to uphold within the social structures, developed over one's course of life with experiences (Burridge, 2014, p. 573). Bourdieu (1989) argues that these social structures dynamically intertwine with the conditions of social actions where the involved actors enact a social logic that results in particular deterministic outcomes that are already dictated by their own cultural and historical backgrounds.

The social world is structured and systematized by fields, which are defined as spaces of positions that partly determine their actors' (or occupants') attributes depending on their characteristics and positioning within these spaces (Bourdieu, 1993). Within each field, actors struggle over its boundaries and who might rightfully belong in these fields (Deem \& Lucas, 2007). Bourdieu concludes that the interrelationship between the habitus and field is termed 'investment', which means the nature to perform within the space (field) and its system of properties (habitus), defining one's inclination, capacity, interest, and struggle.

In each of these social fields, actors struggle to maximize and accumulate forms of capital. In most cases, a person inherits capital from their parents and inherits their parents' social class. Bourdieu (1997) differentiated these capitals as economic (refers to financial and material assets, e.g., monetary wealth), cultural (refers to abstract assets, e.g., educational qualifications, cultural differentiation, language, and acquired taste), and social (refers to social resources, e.g., network of connections and political power). As an overarching concept, symbolic capital includes both the three capitals, mainly referring to networks of social relations (Bourdieu, 1986) where actors are positioned to accumulate within the social field. The struggle within each field, however, also concerns how a particular capital is being recognized and being valued (Deem \& Lucas, 2007). It should also be understood that forms of capital can be interchangeable and interconnected. For example, cultural capital such as getting a Ph.D. degree can help accumulate economic capital or vice-versa. 


\subsection{Methods}

The current paper employs the systematic review procedures to search, select, and extract key findings from various research articles that meet the study's eligibility criteria. The study followed the Preferred Reporting Items for Systematic Review and Meta-Analysis (PRISMA) guidelines (Lall et al., 2019; Moher et al., 2009; Polanin et al., 2017).

Eligibility Criteria. Initially, identified research articles were subject to two criteria for inclusion in the review. First, the paper needed to focus on faculty research productivity in the Philippine context, and second, the article needed to include some discussion of, or interrogation into, various factors that impact faculty research productivity. These papers also needed to be written in English, to involve a range of research methodologies (i.e., qualitative, quantitative, or mixed-method approaches) that investigate the subject matter to collect data from Filipino researchers or faculty members who were involved in research production and to be published in the past ten years (2010 to the present).

Table 1. Overview of the selected studies

\begin{tabular}{|c|c|c|c|}
\hline Authors & Date & Method & Primary Data Source \\
\hline 1. Austria \& Cabonero & 2020 & Quantitative & Survey of 30 academic librarians \\
\hline 2. Barrot et al. & 2020 & Quantitative & $\begin{array}{l}\text { A bibliometric review of } 98 \text { thesis and } \\
\text { dissertations in English Language Teaching (ELT) }\end{array}$ \\
\hline 3. Calma & 2010 & Qualitative & $\begin{array}{l}\text { Interviews of } 2 \text { CHED officials, } 6 \text { ZRC directors, } 28 \\
\text { university executives, and } 17 \text { academic staff }\end{array}$ \\
\hline 4. Capulso & 2020 & Quantitative & Survey of 154 teachers \\
\hline 5. Dumbrique \& Alon & 2013 & Quantitative & $\begin{array}{l}\text { Secondary data from official documents of the } \\
\text { selected university }\end{array}$ \\
\hline 6. Esponilla & 2015 & Quantitative & Survey of faculty members \\
\hline 7. Gamuza \& Pacolor & 2019 & Quantitative & Survey of HEIs top and middle-level managers \\
\hline 8. Gomba \& Pacolor & 2014 & Qualitative & $\begin{array}{l}\text { Interviews of leaders, academic } \\
\text { administrators, presidents, and research managers }\end{array}$ \\
\hline 9. Gonzales et al. & 2020 & Quantitative & Survey of 218 teachers \\
\hline 10. Gravoso et al. & 2016 & Quantitative & $\begin{array}{l}\text { Bibliometric review } 74 \text { research articles in } \\
\text { Developmental Communication }\end{array}$ \\
\hline 11. Mala \& Canencia & 2021 & Quantitative & Survey of 370 faculty members \\
\hline 12. Meneses \& Moreno & 2019 & Quantitative & Survey of 189 faculty members \\
\hline 13. Navarrete \& Asio & 2014 & Quantitative & $\begin{array}{l}\text { A bibliometric review of publications and citations } \\
\text { inSoil Science }\end{array}$ \\
\hline 14. Orale et al. & 2019 & $\begin{array}{l}\text { Mixed } \\
\text { method }\end{array}$ & $\begin{array}{l}\text { Secondary data from official documents, } \\
\text { specifically those recorded or published from } \\
2000 \text { to the present. }\end{array}$ \\
\hline 15. Quitoras et al. & 2021 & Qualitative & $\begin{array}{l}\text { Focus Group Discussions (FGDs) in3higher } \\
\text { education institutions }\end{array}$ \\
\hline $\begin{array}{l}\text { 16. Ramoso \& Ortega- } \\
\text { Dela Cruz }\end{array}$ & 2019 & Quantitative & $\begin{array}{l}\text { Survey of } 52 \text { respondents, including } 34 \text { faculty and } \\
\text { staff and } 18 \text { graduating students. }\end{array}$ \\
\hline 17. Reyes \& Reyes & 2015 & Quantitative & $\begin{array}{l}\text { A bibliometric review of } 261 \text { research articles in } \\
\text { Chemical Engineering, } \\
\text { Education, Literature, Mathematics, Political } \\
\text { Science, and Psychology }\end{array}$ \\
\hline 18. Torres et al. & 2017 & Quantitative & $\begin{array}{l}\text { Survey of } 82 \text { clinical and non-clinical faculty } \\
\text { members }\end{array}$ \\
\hline 19.Vinluan & 2011 & Quantitative & $\begin{array}{l}\text { A bibliometric review of } 214 \text { research articles in } \\
\text { Psychology and Education }\end{array}$ \\
\hline 20. Wong & 2019 & Quantitative & Survey of 191 master teachers \\
\hline
\end{tabular}


Search Procedures. The studies included in this investigation were searched through an extensive search of various electronic databases from June to July 2021. Studies were located from the following databases: ProQuest, Education Resources Information Centre (ERIC), Science Direct, Academic Search Premier, Social Sciences Citation Index, and Google Scholar. Keyword searches used in the literature search included variations of the following terms: "research productivity," "research production," "faculty research productivity," and "Philippine research productivity." Based on these searches, 20 studies are considered eligible for the review (see Table 1).

Appraisal of the studies. Adapting the procedure in the study of Lall et al. (2019), features of the included articles were described according to the following characteristics: a) aim or objectives; b) sample characteristics (i.e., size, population, and locale); c) type of study (e.g., bibliometric review of publications, survey questionnaire of faculty members); and study design (i.e., type of data collection and sampling approach). Also, the quality of the final set of studies was assessed using a tool (Harden, 2007; Rees et al., 2011), where each study is evaluated using seven questions set within two dimensions: trustworthiness and usefulness of findings. In addition, an external reviewer specializing in educational research and sociology independently validated each study as appropriate for the current study.

Data Analysis. As suggested in the literature (Krishnasamy et al., 2016; Lall et al., 2019), the framework analysis approach was employed to organize and analyze the contextual details and findings from each study. This approach involves the construction of thematic categories from key findings of included studies through the use of a matrix (Dixon-Woods, 2011). An important aspect of this approach is the use of a 'priori' framework as the point of analysis for this review. For the purpose of the study, Bourdieusian perspectives on social and capital theory were used to frame and synthesize the findings of included studies deductively. Additional work was performed to ensure that analysis considers the variation across and within different areas and contexts.

\subsection{Results and Discussion}

As noted earlier, 20 studies were included in the systematic review. These were representative of various perspectives on the research productivity of faculty members and teachers in the Philippines. An overview of the selected studies, including the first author, year, methods, and primary data sources, is presented in Table 1. Ten were quantitative studies that employed structured questionnaires and survey to determine RP and factors that impact their RP of various academic staff (Austria \& Cabonero, 2020; Capulso, 2020; Esponilla, 2015; Gamuza \& Pacolor, 2019; Gonzales et al., 2020; Mala \& Canencia, 2021; Meneses \& Moreno, 2019; Ramoso \& Ortega-Dela Cruz, 2019; Torres et al., 2017; Wong, 2019). Five were bibliometric data reviews of published research articles in different areas and disciplines of both hard and soft sciences (Barrot et al., 2020; Gravoso et al., 2016; Navarrete \& Asio, 2014; Reyes \& Reyes, 2015; Vinluan, 2012). Three were qualitative studies that employed interviews and FGDs of institutional stakeholders concerning RP (Calma, 2010; Gomba \& Pacolor, 2014; Quitoras $\&$ Abuso, 2021). And two used secondary data, such as official documents, policies, and faculty research outputs, to determine the university's RP (Dumbrique \& Alon, 2013; Orale et al., 2019). These studies included in the review investigated a wide range of variables and factors in RP. Table 2 presents an overview of the key findings of the included studies.

During the literature review, two distinct themes emerged. Framing RP in Bourdieu's theory, faculty members are confronted with two hurdles: (a) the struggle for legitimization and (b) the paradox of policies and practices. Dispositions or habitus are defined and differentiated by virtue of power relations in society, and thus, confer upon social advantage or disadvantage (Grenfell, 2008). For many university faculty members, their research productivity reflects their perception of the value of research engagement and publication, as well as institutional factors that influence the shaping of these constructs. The following sections examine the individual characteristics and institutional factors that manifest faculty research productivity as a capital.

\section{Struggle for Legitimization}

The literature on RP has considered the importance of looking into the various individual characteristics of the key players in the HEIs, mainly its faculty members. As an initial analysis, demographics are vital in providing a full description of the experiences of faculty members. Gender, for example, is considered as an important determinant as there are still more male scholars who are publishing compared to female scholars (Reyes \& Reyes, 2015). As highlighted in the literature, 
Table 2. Key findings of the selected studies

\begin{tabular}{ll}
\hline \multicolumn{1}{c}{ Authors \& Date } & \multicolumn{1}{c}{ Key Findings } \\
\hline 1. Austria \& Cabonero (2020) & $\begin{array}{l}\text { Identified librarians, even with proficient skills in research, } \\
\text { lacked financial and academic resources (i.e., materials in } \\
\text { research topics and methods) to do research. }\end{array}$ \\
2. Barrot et al. (2020) & $\begin{array}{l}\text { Identified that most of the scope of ELT theses and } \\
\text { dissertations are limited into select areas of the discipline } \\
\text { because of the absence of a clear ELT research agenda }\end{array}$ \\
3. Calma (2010) & $\begin{array}{l}\text { Found that funding for research affects one's graduate } \\
\text { research degree (GRD) and the type of research } \\
\text { undertaken. } \\
\text { Identified that developing research competencies and } \\
\text { motivation to undertake research is also an issue with staff } \\
\text { engaging in research }\end{array}$
\end{tabular}

4. Capulso (2020)

- Identified research competencies of faculty members in a school division where there is a need for enhanced and unified research feedback and monitoring mechanism, need-based capacity building, and school-based incentive mechanism.

5. Dumbrique \& Alon (2013)

6. Esponilla (2015)

7. Gamuza \& Pacolor (2019)

8. Gomba \& Pacolor (2014)

9. Gonzales et al. (2020)

10. Gravoso et al. (2016)

11. Mala \& Canencia (2021)

12. Meneses \& Moreno (2019)

13. Navarrete \& Asio (2014)

14. Orale et al. (2019)

15. Quitoras et al. (2021)

16. Ramoso \& Ortega-Dela Cruz (2019)

17. Reyes \& Reyes (2015)

18. Torres et al. (2017)

19. Vinluan (2012)

20. Wong (2019)
- Found educational attainment and membership in scientific/research organizations came out as good indicators of faculty research productivity.

- Revealed no statistically significant linear dependence of the mean of research productivity on the predictors such as researchers' qualifications, intrinsic and extrinsic motivation factors.

- Found no significant relationship identified between research productivity and leadership orientation.

- Identified Research and Development (R\&D) leadership qualities can be attributed to the improvement of the number of faculty and personnel involved in R\&D.

- Identified how higher educational attainment and attendance to national training improve research skills and knowledge in the research process and dissemination.

- Revealed that research productivity of Developmental Communication in the Philippines is low

- Found that geographical location of the campus or university has no significant relationship on publishing research papers.

- Identified how research productivity of the faculty members can be associated with external and internal factors.

- Proposed a paradigm shift in soil science research from mostly rice-related research to environmental research.

- Improved performance in R\&D was greatly attributed to the clearance policy (an external force) of the university, where rewards provide an additional push.

- Revealed that the best practices among research programs are intended to develop and sustain research culture.

- Emphasized how research agenda themes of the National Higher Education Research Agenda (NHERA) should be prioritized by the institution.

- Found that the percentage of female contribution and participation remained almost unchanged in the past years with significant differences among disciplines.

- Identified how current teaching assignments hinder the capacity to conduct research.

- Identified that university-sponsored incentives and collegebased research services had remained underutilized despite their availability.

- Showed that the Philippines ranked low in research productivity compared to other ASEAN countries.

- Found a correlation between research capability and personal-related variables (e.g., age, length of service, teaching position, training attended, research conducted, research project involvement, research knowledge, attitude towards research, and institutional support). 
academic rank and qualifications have been revealed as a significant predictor of research productivity among faculty members. Faculty members who have obtained higher educational attainments and national training were shown to be more skilled and knowledgeable in the research process and dissemination (Gonzales et al., 2020). There is also a tendency for higher-ranking faculty members to be more research productive (Gamuza \& Pacolor, 2019). Psychological traits, like motivation and selfefficacy, are also considered as major indicators of RP among faculty members. Studies presented how extrinsic motivation influences faculty research production, such as incentives and promotions, to a great extent (Esponilla, 2015; Meneses \& Moreno, 2019; Torres et al., 2017).

Aside from academic qualifications, the majority of the literature also focused on investigating faculty members' research capacity skills. Generally, it was revealed that faculty members are proficient and highly knowledgeable in the early phases of the research process, i.e., conceptualizing research problems, reviewing related literature, and designing the research study (Austria \& Cabonero, 2020; Meneses \& Moreno, 2019; Torres et al., 2017). As expected, low research capability is directly linked with the limited knowledge of faculty members in aspects of research (Wong, 2019). This can be attributed to the low enrollment and attrition of these faculty members in graduate programs (Barrot et al., 2020). Regardless of one's research knowledge and academic experiences, some faculty members are still hesitant to undertake research activities that can be a result of institutional restrictions (Mala \& Canencia, 2021). The literature on RP revealed how academic qualifications and research skills are important factors for the legitimization of faculty members in their professional fields. Findings of the literature revealed various struggles of faculty members, from obtaining higher education to attending training, just to capacitate themselves in research because this will determine their longevity and hierarchy in the academe.

Individual characteristics of faculty members that determine their RP can be easily framed as their cultural capital. Bourdieu (1986) initially devised this type of capital in an attempt to explain the unequal scholarly achievements of students from differing social classes. Similarly, this type of capital can also be attributed to the discrepancy of RP among academics in the field. One's research capacity can be classified as 'embodied cultural capital', which Bourdieu defined as "the composite set of skills, dispositions, practices, knowledges 'embodied' by an individual" (Carrington \& Luke, 1997, p. 102). This has resulted in numerous inquiries on the research competence of faculty members as a determinant of their capability for research production. On the other hand, one's academic qualifications can be referred to as 'institutional cultural capital', which are granted and authorized by social institutions like schools and universities. With this capital's shared recognition by the state and the professional field, Bourdieu posited a direct comparison of credentials (e.g., degrees and diplomas) and its conversion to economic capital; thus, creating market value for one's academic qualifications. With the literature emphasizing the need to improve these characteristics among faculty members, the field of the academe enforces the continuous accumulation of cultural capital to keep up with the demands of RP, resulting in internalized professional struggles.

The struggles of faculty members to adhere to particular academic expectations and to legitimize themselves through research are just some examples of the internalized conflict of professionals. Framing this notion to Bourdieusian perspectives, the university becomes the field of struggle among faculty members where they try to continually accumulate capital; whereas, the struggling agents are the faculty members and the academics. With the selected studies in this paper, the majority of the interrogation are situated in various state universities that have research policies and practices determined by the Philippine Commission on Higher Education (CHED). As a result, the research policies of these universities are more or less likely to be homogenous. Even though Bourdieu had little to say about the concept of professionalism, Noordegraaf and Schinkel $(2011$, p. 68, 89) argued that professional capital is a useful extension of Bourdieu's frame and that "professionalism can be seen as a form of symbolic capital in ... the 'field of power'". Because of the demands of the field, research productivity has become a form of professional capital where faculty members try to accomplish as part of their job in the university. Recognizing professional capital as an arbitrated form of symbolic capital is vital in analyzing the process of "professionalization" as a continuing struggle to attain symbolic capital. Essentially, professional capital concerns how various professional fields position and differentiate themselves from each other.

In education, Hargreaves and Fullan (2015) used this term to refer to how schools capitalize and invest in the collective human, social and decisional capital of their teachers. This notion focuses on the economic aspect of institutions towards investing in their faculty members. Most studies identified 
that faculty members' research motivation was extrinsically driven by incentivizing research production and equating research to faculty promotions. This type of institutional practice, however, may only add pressure and power struggle to an already competitive field that may impact inequalities in the teaching and research habitus of these faculty members. In effect, research productivity becomes a value internalized intrinsically by the faculty members practicing in the profession. In an event where capital as an arbitrary tool pretends to hold intrinsic value, it only inflicts "symbolic violence" (Bourdieu, 1997), where the manifestation of non-physical violence through power differential occurs. This power differential can be reflected in the unconscious struggle of legitimizing oneself within academic institutions, which can lead to exploitative practices (e.g., the increase of predatory journal publications) and unrealistic policies (e.g., annual international publication requirement for faculty members) just to accumulate such symbolic capital.

\section{Paradox of policies and practices}

Another issue that faculty members face is their struggle to overcome the paradox of national policies that encourage RP, and institutional practices that inhibit and restrict RP among faculty members. This argument can be rooted in the absence of fully functioning research universities in the country (Demeterio \& Pada, 2018; 2019), where the majority of universities are still prioritizing dichotomous activities of teaching and research. With academics and faculty members balancing their workload with both teaching and research responsibilities, these agents are faced with overwhelming expectations to excel in both aspects. Therefore, this creates an additional burden for faculty members to cope with these demands and to scout organizations outside the structure of the academe that allow the full support of their research undertakings. As Demeterio and Pada $(2018$; 2019) claim, situating academics in a real research university can produce focused academic directions towards research production. It should be noted that research can truly be productive and supported, with minimal difficulties and paradoxes, if situated in a real existing research university. As compensation for the lack of a research university, CHED continuously advocates policies that gear towards improving research production and research orientation. Through the Republic Act (RA) 7722, "Higher Education Act of 1994", faculty members are essentially mandated to perform tri-focal functions of teaching, research, and community service. Furthermore, UNESCO World Declaration on Higher Education for the 21st Century stated that:

\footnotetext{
higher education institutions (HEIs) should advance, create and disseminate knowledge through research. They should provide, as part of their service to the community, relevant expertise to assist societies in cultural, social, and economic development. They should promote and develop scientific and technological research as well as research in the social sciences, the humanities, and the creative arts (Gomba \& Pacolor, 2014, p. 114).
}

These mandates led to the development of the NHERA that creates the policies and thrusts of Philippine higher education research. This initiative encourages collaborations among networks of HEIs in the country and promotes partnerships of HEIs with other research institutions, national and international. Even with these initiatives, the Philippines still exhibited low research productivity in the soft sciences (Barrot et al., 2020; Gravoso et al., 2016; Vinluan, 2012), hard sciences (Navarrate \& Asio, 2014), and business research (Dumbrique \& Alon, 2013). This is where the paradox of national policies and institutional practices occurs in terms of research-related initiatives. Policies, in paper at least, encourage and promote research productivity among faculty members, but practicing research in a school system where there are a lot of restrictions can be oftentimes problematic and difficult.

The majority of the issues found in the literature on faculty research productivity are attributed to the existing institutional factors of the HEIs. Several factors that attributed to the low RP of the country concerned mainly with institutional factors such as HEIs' 'low research intensity (Hien, 2010), limited research funding (Calma, 2010), the underdeveloped epistemic culture of knowledge production (Vinluan, 2012), and misalignment of institutional research initiatives to the national research agenda (Ramoso \& Ortega-Dela Cruz, 2019). One notable finding is the significance of one's workload to greatly influence RP (Austria \& Carbonero, 2020; Torres et al., 2017). Faculty members attribute their low RP to their extensive workload that restricts them from undertaking research works. This can be a result of Philippine universities primarily being known to be teaching universities that might not have enough institutional support towards improving the research competencies of faculty members. 
Institutional research culture is also highlighted that influences teachers' research engagement (Almonte-Acosta, 2007; Wong, 2019). This is evident with the findings in the case of Samar State University, where their research and development (R\&D) area has undergone a transformation process to change management for improving RP (Orale et al., 2019). On the contrary, it was revealed that the leadership orientation of State University and Colleges (SUC) administrators and managers do not really provide a significant positive influence in terms of the research productivity of the institution (Gamuza \& Pacolor, 2019). Another finding is the relevance of having research programs to develop and sustain research culture among faculty members (Quitoras \& Abuso, 2021). Ideally, a strong institutional research culture manifests through academic leaders that transcend research culture and contextualize it to the needs of the faculty. However, the findings showed that institutional research culture, or the lack thereof, only resulted in negative implications on faculty RP.

The paradox between policies and practices only creates an additional layer of characterization of the social structure where university faculty members have to struggle with to accumulate symbolic capital in their respective fields. Analyzing these issues on RP within the institutional context, symbolic power has a tendency to reproduce through objective power relations (Bourdieu, 1994). In this struggle for research production ('high research productivity' or 'low research productivity' in this context), the actors, as Bourdieu says, "tend to put into action the symbolic capital they have acquired in previous struggles" (p. 135). Research productivity as a capital, therefore, is socially constructed; is mediated by historical and political forces; and is a result of power inequalities in the society (Bunar \& Ambrose, 2016). Bourdieu even stated that:

[o]wing to the fact that symbolic capital is nothing other than economic or cultural capital when it is known and recognized, when it is known through the categories of perception that it imposes, symbolic relations of power tend to reproduce and to reinforce the power relations that constitute the structure of social space. (pp. 134-135)

Bourdieu argued that these conditions that have been legitimized in the social world were not a product of conscious action or symbolic imposition; but rather from the fact that actors (or agents) manifest certain perceptions and appreciation towards these objective structures issued out by the very structures of the social world. Research productivity as symbolic capital, as put into action in this analysis, is never solely a product of institutional policies of trying to motivate teachers to conduct more research but of how the social field of the academe enacts power relations through this capital. This form of capital has the power to be recognized, valued, and desired (be it an internationally published academician or a faculty-researcher with numerous grants and funding). This ultimately echoes and contributes to perpetuating power relations, as Bourdieu says, to constitute social structures within the context of HEIs' demand of research production among faculty members.

\subsection{Conclusion}

In conclusion, the paper tried to relate how research productivity becomes a capital where actors, faculty members in this case, continuously struggle to accumulate this capital through legitimizing themselves through research and overcoming the conflicting policies and practices of institutions. The analysis presented how motivation to conduct research underpinned the desire of faculty members to acquire professional capital to legitimize themselves as part of their respective social fields. Similarly, institutions invest in the creation of this professional capital by improving the economic capital of their faculty members through research incentives and promotions. The analysis also showed how institutional factors such as workload and research culture enable the perpetuation of power relations through possession of this form of symbolic capital. As a result, faculty members are extrinsically, and most of the time unconsciously, struggling and imposing these power relations among themselves and each other because of the norms socially-constructed and construed by their own respective fields. Given that this paper only interrogated this issue theoretically and only looked into past literature, future research can highlight empirical investigations on the various claims of the study. 


\section{REFERENCES}

Alghanim, S. A., \& Alhamali, R. M. (2011). Research productivity among faculty members at medical and health schools in Saudi Arabia. Saudi Medical Journal, 32(12), 1297-1303.

Alhija, F. M. N. A., \& Majdob, A. (2017). Predictors of teacher educators' research productivity. Australian Journal of Teacher Education, 42(11), 34-51.

Almonte-Acosta, S. A. (2007). Developing research culture in Philippine higher education institutions: Perspectives of university faculty Rose Marie Salazar-Clemeña, Ph.D. Dean, College of Education De La Salle UniversityManila. Ph.D. Dean, College of Education De La Salle University-Manila.

Altbach, P. G. (2011). The past, present, and future of the research university. Economic and Political Weekly, 65-73. https://www.jstor.org/stable/41152107

Austria, R. M., \& Cabonero, D. A. (2020). Research knowledge and skills of academic librarians in Northern Philippines. Library Philosophy and Practice. 3976.

Barker, P. (2005). Research in schools and colleges. National Educational Research Forum Working Paper 7.2.

Barrot, J. S., Acomular, D. R., Alamodin, E. A., \& Argonza, R. C. R. (2020). Scientific mapping of English language teaching research in the Philippines: A bibliometric review of doctoral and master's theses (20102018). RELC Journal, 1-14. https://doi.org/10.1177/0033688220936764

Batool, A., Hussain, A. C., \& Ahmad, S. (2018). Identification of institutional factors of research productivity of public universities teachers. Journal of Educational Research (1027-9776), 21(2).

Beckmann, A., \& Cooper, C. (2013). Neoliberal globalization, managerialism and higher education in England: Challenging the imposed "order of things". Educational Policy Analysis and Strategic Research, 8(1), 5-24. https://eric.ed.gov/?id=EJ1127600

Bland, C. J., Center, B. A., Finstad, D. A., Risbey, K. R., \& Staples, J. G. (2005). A theoretical, practical, predictive model of faculty and department research productivity. Academic Medicine, 80(3), 225-237.

Bloedel, J. R. (2001). Judging research productivity on an entrepreneurial campus. Evaluation Research Productivity, 105.

Borg, S. (2007). Research engagement in English language teaching. Teaching and Teacher Education, 23(5), 731747. https://doi.org/10.1016/j.tate.2006.03.012

Bourdieu, P. (1977). Outline of a theory of practice. Cambridge University Press.

Bourdieu, P. (1984). Distinction: A social critique of the judgment of taste. Routledge.

Bourdieu, P. (1986). The forms of capital. In J. G. Richardson (Ed.), Handbook of theory and research for the sociology of education (pp. 241-258). Greenwood Press.

Bourdieu, P. (1988). Homo academicus. Stanford University Press.

Bourdieu, P. (1989). Social space and symbolic power. Sociological Theory, 7(1), 14-25. https://doi. org/10.2307/202060

Bourdieu, P. (1993). Sociology in question. Sage.

Bourdieu, P. (1994). In other words. Cambridge University Press.

Bourdieu, P. (1997). The forms of capital. In A. H. Halsey, H. Lauder, P. Brown, \& A. S. Wells (Eds.), Education: Culture, economy, and society (pp. 46-58). Oxford University Press.

Bourdieu, P. (2002). The politics of globalization. Open Democracy, 1-4.

Burridge, P. (2014). Understanding teachers' pedagogical choice: A sociological framework combining the work of Bourdieu and Giddens. Educational Studies, 40(5), 571-589. https://doi.org/10.1080/03055698.2014.953915

Bunar, N., \& Ambrose, A. (2016). Schools, choice and reputation: Local school markets and the distribution of symbolic capital in segregated cities. Research in Comparative and International Education, 11(1), 34-51. https://doi.org/10.1177/1745499916631064

Calma, A. (2010). Funding for research and research training and its effects on research activity: The case of the Philippines. The Asia-Pacific Education Researcher, 19, 213-228.

Capulso, L. B. (2020). Research productivity of select secondary schools in Central Luzon, Philippines. Journal of World Englishes and Educational Practices, 2(2), 1-11.

Carrington, V., \& Luke, A. (1997). Literacy and Bourdieu's sociological theory: A reframing. Language and Education, 11(2), 96-112. https://doi.org/10.1080/09500789708666721

Creswell, J. W. (1986). Measuring faculty research performance. Jossey-Bass Inc.

De Villiers, A. P., \& Steyn, A. G. W. (2009). Effect of changes in state funding of higher education on higher education output in South Africa: 1986-2007. South African Journal of Higher Education, 23(1), 43-68. https://hdl.handle.net/10520/EJC37517

Deem, R., \& Lucas, L. (2007). Research and teaching cultures in two contrasting UK policy contexts: Academic life in education departments in five English and Scottish universities. Higher Education, 54(1), 115-133. https:// doi.org/10.1007/s10734-006-9010-z

Demeterio III, F. P. A., \& Pada, R. T. D. (2018). A Humboldtian critique of the University of the Philippines as the flagship of Philippine higher education (Part I). Kritike, 12(2), 64-90.

Demeterio III, F. P. A., \& Pada, R. T. D. (2019). A Humboldtian critique of the University of the Philippines as the flagship of Philippine higher education (Part II). KRITIKE: An Online Journal of Philosophy, 13(1) 48-77.

Dixon-Woods, M. (2011). Using framework-based synthesis for conducting reviews of qualitative studies. BMC Medicine, 9(1), 1-2. https://doi.org/10.1186/1741-7015-9-39 
Dumbrique, J. S., \& Alon, T. D. (2013). Research productivity of business administration and accountancy faculty, University of Northern Philippines, Vigan City. IAMURE International Journal of Education, 6(1). http://www. ejournals.ph/form/cite.php?id=3224

Esponilla II, F. (2015). Motivators of research productivity level in the technological university of the Philippines (TUP), Manila Campus. Proceedings in ICMSIT 2015: International Conference on Management Science, Innovation, and Technology. 108-121. https://www.researchgate.net/

Gamuza, E. V., \& Pacolor, E. T. (2019). Research productivity of SUC managers in Eastern Visayas, Philippines, and their leadership orientation. Journal of Academic Research, 4(3), 23-30. https://jar.ssu.edu.ph/index.php/JAR/ article/view/6

Giroux, H. A. (2002). Neoliberalism, corporate culture, and the promise of higher education: The University as a democratic public sphere. Harvard Educational Review, 72(4), 425-463. https://doi.org/10.17763/ haer.72.4.0515nr62324n71p1

Giroux, H. A. (2012). Neoliberalism, youth, and the leasing of higher education. In D. Hill \& R. Kumar (Eds.), Global neoliberalism and education and its consequences, (pp. 50-73). Routledge.

Gomba, F. E., \& Pacolor, E. T. (2014). Transforming research and development culture from a technical-vocational based institution to a research university: Samar State University, Philippines case. Countryside Development Research Journal, 2(01), 143-151.

Gonzales, I. B., Corpuz, D. A., \& Dellosa, R. M. (2020). Research capabilities of public elementary school teachers and management support of the schools division of Nueva Vizcaya, Philippines. Humanities \& Social Sciences Reviews, 8(4), 2020. https://doi.org/10.18510/hssr.2020.8427

Gravoso, R. S., Navarrete, I. A., \& Gahoy, I. K. P. (2016). Research productivity in development communication in the Philippines. Annals of Tropical Research, 38(2), 166-173. https://annalsoftropicalresearch.com/

Grenfell, M. (Ed.). (2008). Pierre Bourdieu key concepts. Acumen.

Harden A. (2007). Qualitative research, systematic reviews, and evidence-informed policy and practice. University of London.

Hargreaves, A., \& Fullan, M. (2015). Professional capital: Transforming teaching in every school. Routledge.

Hien, P. D. (2010). A comparative study of research capabilities of East Asian countries and implications for Vietnam. Higher Education, 60, 615-625. https://doi.org/10.1007/s10734-010-9319-5

Iqbal, M. Z., \& Mahmood, A. (2011). Factors related to low research productivity at the higher education level. Asian Social Science, 7(2), 188-193.

Ju, M. (2010). The impact of institutional and peer support on faculty research productivity: A comparative analysis of research vs. non-research institutions. Seton Hall University.

Jung, J. (2012). Faculty research productivity in Hong Kong across academic discipline. Higher Education Studies, 2(4), 1-13. http://www.ccsenet.org/journal/index.php/hes

Kotrlik, J. W., Bartlett, J. E., Higgins, C. C., \& Williams, H. A. (2002). Factors associated with research productivity of agricultural education faculty. Journal of Agricultural Education, 43(3), 1-10. https://doi.org/10.5032./ jae.2002.03001

Krishnasamy, C., Ong, S. Y., Yock, Y., Lim, I., Rees, R., \& Car, J. (2016). Factors influencing the implementation, adoption, use, sustainability and scalability of mLearning for medical and nursing education: A systematic review protocol. Systematic reviews, 5(1), 1-8. https://doi.org/10.1186/s13643-016-0354-x

Kusure, L. P., Mutanda, L., Mawere, D., \& Dhliwayo, L. (2006). Factors influencing research productivity among lectures in teachers' colleges in Zimbabwe. Southern Africa Journal of Education, Science, and Technology, 1(2), 118-124.

Lall, P., Rees, R., Law, G. C. Y., Dunleavy, G., Cotič, Ž., \& Car, J. (2019). Influences on the implementation of mobile learning for medical and nursing education: Qualitative systematic review by the digital health education collaboration. Journal of Medical Internet Research, 21(2), 1-16. http://dx.doi.org/10.2196/12895

Lertputtarak, S. (2008). An investigation of factors related to research productivity in a public university in Thailand: A case study. Victoria University.

Levidow, L. (2002). Marketizing higher education: Neoliberal strategies and counter-strategies. In K. Robins \& F. Webster (Eds.), The virtual university? Knowledge, markets, and management, (pp.227-248). Oxford University Press.

Livingston, K., McCall, J., \& Morgado, M. (2009). Teacher educators as researchers. In. A. Swennen \& M. van der Klink (Eds.), Becoming a teacher educator. Theory and Practice_for Teacher Educators. UK: Springer. https:// doi.org/10.1007/978-1-4020-8874-2_14

Mala, C. M., \& Canencia, O. P. (2021). Influence of ethnicity and geographical location on research productivity in Mindanao State University System, Philippines. American Journal of Educational Research, 9(1), 20-30.

Meneses, J. L., \& Moreno, N. I. (2019). Factors influencing research productivity of Rizal Technological University: Input to research capability development program. International Journal of Education and Research, 7(3), 85-110.

Middaugh, M. F. (2000). Analyzing costs in higher education: What institutional researchers need to know? JosseyBass Inc.

Moher, D., Liberati, A., Tetzlaff, J., Altman, D. G., \& Prisma Group. (2009). Preferred reporting items for systematic reviews and meta-analyses: The PRISMA statement. PLoS Medicine, 6(7). https://doi.org/10.1371/journal. pmed.1000097 
Navarrete, I. A., \& Asio, V. B. (2014). Research productivity in soil science in the Philippines. Scientometrics, 100(1), 261-272. https://doi.org/10.1007/s11192-013-1202-6

Noordegraaf, M., \& Schinkel, W. (2011). Professionalism as symbolic capital: Materials for a Bourdieusian theory of professionalism. Comparative Sociology, 10(1), 67-96. https://doi.org/10.1163/156913310X514083.

Orale, R. L., Cardoso, M. D., \& Gomba, F. E. (2019). R\&D Transformation model of public higher education institution in the Philippines: Case of Samar State University. Journal of Academic Research, 4(3), 1-22. https://jar.ssu.edu.ph/index.php/JAR/article/view/5

Peng, J. E., \& Gao, X. (2019). Understanding TEFL academics' research motivation and its relations with research productivity. Sage Open, 9(3), 1-13. https://doi.org/10.1177/2158244019866295

Polanin, J. R., Maynard, B. R., \& Dell, N. A. (2017). Overviews in education research: A systematic review and analysis. Review of Educational Research, 87(1), 172-203. https://doi.org/10.3102\%2F0034654316631117

Quitoras, M. C. L., \& Abuso, J. E. (2021). Best practices of Higher Education Institutions (HEIs) for the development of research culture in the Philippines. Pedagogical Research, 6(1), 1-7.

Ramoso, M. G. D., \& Ortega-Dela Cruz, R. A. (2019). Relevance of the national research agenda to the research initiative of a higher education institution in the Philippines. Asian Journal of University Education, 15(2), 1-11. https://education.uitm.edu.my/ajue/

Rees, R., Oliver, K., Woodman, J., \& Thomas, J. (2011). The views of young children in the UK about obesity, body size, shape, and weight: A systematic review. BMC Public Health, 11(1), 1-12. https://doi.org/10.1186/14712458-11-188

Reyes, C. N., \& Reyes, J. A. L. (2015). Exploring publication productivity in the Philippines: A 10-year gendered analysis of six academic disciplines. Asia-Pacific Social Science Review, 15(1), 26-45.

Steck, H. (2003). Corporatization of the university: Seeking conceptual clarity. The Annals of the American Academy of Political and Social Science, 585(1), 66-83. https://doi.org/10.1177/0002716202238567

Torres, G. C. S., Estrada, M. G., Sumile, E. F. R., Macindo, J. R. B., Maravilla, S. N., \& Hendrix, C. C. (2017). Assessment of research capacity among nursing faculty in a clinical intensive university in the Philippines. Nursing forum, 52(4), 244-253.

Vinluan, L. R. (2012). Research productivity in education and psychology in the Philippines and comparison with ASEAN countries. Scientometrics, 91(1), 277-294. https://doi.org/10.1007/s11192-011-0496-5

White, C. S., James, K., Burke, L. A., \& Allen, R. S. (2012). What makes a "research star"?: Factors influencing the research productivity of business faculty. International Journal of Productivity and Performance Management. 61(6), 584-602. https://doi.org/10.1108/17410401211249175

Wilensky, H. L. (1964). The professionalization of everyone? American Journal of Sociology, 70(2), 137-158. https:// doi.org/10.1086/223790

Wong, A. M. (2019). Driving forces of master teachers' research capability: Towards building a research culture in the division of Romblon, Philippines. International Journal of Advanced Research and Publications, 3(7), 92-97.

Zhang, X. (2014). Factors that motivate academic staff to conduct research and influence research productivity in Chinese project 211 universities. University of Canberra.

\section{Correspondence:}

HOLDEN KENNETH G. ALCAZAREN

hkgalcazaren@gmail.com

https://orcid.org/0000-0002-9684-6961 